\title{
Analisis Penerimaan e-Learning Menggunakan Technology Acceptance Model (TAM) (Studi Kasus: Universitas Atma Jaya Yogyakarta)
}

\author{
Flourensia Sapty Rahayu ${ }^{1}$, Djoko Budiyanto ${ }^{2}$, David Palyama ${ }^{3}$ \\ ${ }^{1}$ Prodi Sistem Informasi, Universitas Atma Jaya Yogyakarta \\ Jl. Babarsari 43 Jogjakarta \\ sapty@mail.uajy.ac.id \\ ${ }^{2}$ Prodi Teknik Informatika, Universitas Atma Jaya Yogyakarta \\ Jl. Babarsari 43 Jogjakarta \\ djoko@mail.uajy.ac.id \\ ${ }^{3}$ Prodi Teknik Informatika, Universitas Atma Jaya Yogyakarta \\ Jl. Babarsari 43 Jogjakarta \\ davidpalijama@gmail.com
}

\begin{abstract}
One crucial consideration of implementing an information system is the users' acceptance and the users' willingness in using the system. The Information system implementation may be a failure if users do not accept or are unwilling to use the information system. As an educational institution, Universitas Atma Jaya Yogyakarta (UAJY) provided an e-learning system to support teaching and learning process. The main users of the e-learning system are lecturers and students. There has never been any evaluation conducted to evaluate user acceptance since the implementation of the system. This study was conducted to evaluate the user acceptance of elearning by using Technology Acceptance Model (TAM). The evaluation was done by measuring the influence between variables in TAM model which includes Perceived Ease of Use, Perceived Usefulness, Attitude Toward Using, Behavioral Intention and Actual Usage. Statistical methods that are used in this research are validity test, reliability test, normality test, and Structural Equation Model (SEM). Data were obtained from questionnaire distributed to students of all faculties in UAJY. Among the six hypotheses proposed, the hypothesis that states "Perceived Usefulnes" influence "Behavioral Intention" is not accepted. The other five hypotheses which are "Perceived Ease of Use" influence "Perceived Usefulness", "Perceived Usefulnes" influence "Attitude Toward Using", "Perceived Ease of Use" influence "Attitude Toward Using", "Attitude Toward Using" influence "Behavioral Intention", "Behavioral Intention" influence "Actual Usage" otherwise acceptable.
\end{abstract}

Keywords-user acceptance analysis, e-learning, Technology Acceptance Model (TAM)

Intisari-Dalam implementasi sebuah sistem informasi di suatu institusi, perlu dipertimbangkan penerimaan pengguna terhadap sistem informasi tersebut. Penerapan sistem informasi dapat dikatakan gagal jika pengguna ternyata tidak dapat menerima atau tidak bersedia menggunakan sistem informasi tersebut. Sebagai sebuah institusi pendidikan, Universitas Atma Jaya Yogyakarta (UAJY)juga mengimplementasikan sistem e-learning untuk mendukung proses belajar mengajar. Pengguna wajib dari e-learning ini adalah dosen dan mahasiwa. Sejak sistem diterapkan, belum pernah diadakan evaluasi mengenai penerimaan pengguna terhdap sistem e-learning ini. Penelitian ini dilakukan untuk melakukan pengujian terhadap penerimaan pengguna (mahasiswa) terhadap e-learning dengan menggunakan Technology Acceptance Model (TAM). Pengujian dilakukan dengan mengukur pengaruh antar variabel dalam model TAM yang meliputi variabel Perceived Ease of Use, Perceived Usefulness, Attitude Toward Using, Behavioral Intention dan Actual Usage. Metode pengujian statistik yang dilakukan yaitu uji statistik validitas, reliabilitas, normalitas, dan menguji pengaruh faktor menggunakan Structural Equation Model (SEM). Data evaluasi diperoleh melalui kuesioner yang dibagikan kepada responden mahasiswa UAJY dari seluruh fakultas. Dari enam hipotesis yang diajukan satu hipotesis dinyatakan tidak diterima, yaitu hipotesis yang menyatakan Perceived Usefulnes berpengaruh terhadap Behavioral Intention. Kelima hipotesis yang lain yaitu Perceived Ease of Use berpengaruh terhadap Perceived Usefulnes, Perceived Usefulnes berpengaruh terhadap Attitude Toward Using, Perceived Ease of Use berpengaruh terhadap Attitude Toward Using, Attitude Toward Using berpengaruh terhadap Behavioral Intention, Behavioral Intention berpengaruh terhadap Actual Usage dinyatakan dapat diterima.

Kata Kunci-analisis penerimaan pengguna, e-learning, Technology Acceptance Model (TAM)

\section{Pendahuluan}

Peningkatan kualitas pendidikan merupakan hal yang penting yang harus dilakukan oleh setiap institusi pendidikan. Pemanfaatan kemajuan ilmu pengetahuan dan teknologi perlu dilakukan agar mampu mencapai tujuan organisasi secara efektif dan efisien [1]. Universitas Atma Jaya Yogyakarta (UAJY) merupakan salah satu universitas di Yogyakarta, yang telah memanfaatkan e-learning. Dengan e-learning mahasiswa dapat mengakses materi kuliah yang ditempuh, melakukan diskusi pada forum, dan juga mengirimkan berkas-berkas untuk keperluan perkuliahan. Semua layanan akademik tersebut dapat diakses melalui halaman web dengan alamat http://kuliah.uajy.ac.id. ELearning UAJY sudah mulai diperkenalkan dari tahun 2007 , 
namun sampai dengan saat ini belum pernah dilakukan evaluasi tentang penggunaan e-learning ini.

Tingkat penerimaan sistem informasi oleh pengguna dapat menjadi suatu tolak ukur untuk menilai penerimaan sebuah teknologi informasi oleh pengguna. Salah satu metode yang dapat digunakan untuk mengukur penerimaan dan penggunaan teknologi adalah metode Technology Acceptance Model (TAM). Technology Acceptance Model (TAM) merupakan suatu model hasil pengembangan dari Theory of Reasoned Action (TRA) oleh Davis [2] yang mempelajari perilaku penerimaan seorang individu dalam menerima suatu sistem informasi. Seiring dengan perkembangan teori mengenai model penerimaan, TAM sendiri saat ini telah mengalami beberapa perubahan TAM2 [3], dan UTAUT [4].

Penelitian ini bertujuan untuk melihat dan mengetahui faktor-faktor yang berpengaruh dalam penerimaan $e$ learning oleh pengguna, khususnya mahasiwa, dan dampaknya bagi pengguna serta pihak UAJY. Dari hasil penelitian diharapkan dapat memberikan informasi kepada pihak berwenang tentang faktor-faktor yang mempengaruhi minat dari mahasiswa dalam menggunakan situs kuliah sehingga penggunaan e-learning dapat dimaksimalkan.

\section{KAJIAN PUSTAKA}

TAM yang diperkenalkan pertama kali oleh Fred D. Davis pada tahun 1986 [5] adalah adaptasi dari TRA (Theory of Reasoned Action) [6] yang dibuat khusus untuk pemodelan penerimaan penggunaan terhadap sistem informasi. Menurut Davis [5], tujuan utama TAM adalah untuk memberikan dasar untuk penelusuran pengaruh faktor eksternal terhadap kepercayaan, sikap, dan tujuan pengguna. TAM menganggap bahwa 2 keyakinan individual, yaitu persepsi manfaat (perceived usefulness, disingkat PU) dan persepsi kemudahan penggunaan (perceived easy of use, disingkat PEOU), adalah pengaruh utama untuk perilaku penerimaan komputer. Dalam memformulasikan TAM, Davis [5] menggunakan TRA sebagai grand theorynya namun tidak mengakomodasi semua komponen teori TRA seperti yang tergambarkan dalam gambar 1. Davis [5] hanya memanfaatkan komponen 'Belief' dan 'Attitude' saja, sedangkan Normative Belief dan Subjective Norms tidak digunakannya. Secara skematik teori TAM tergambar dalam Gambar 1 [7].

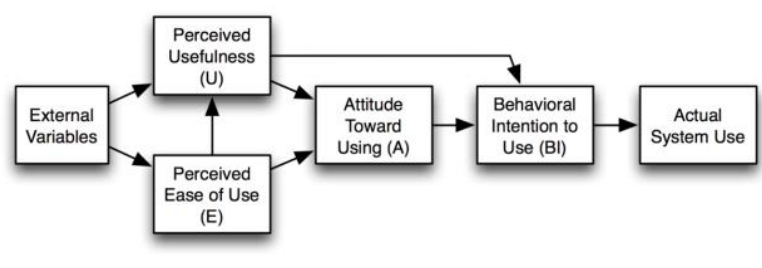

Gambar 1. Technology Acceptance Model [7]

Persepsi kegunaan (perceived usefulness) menggambarkan tingkat kepercayaan seseorang bahwa penggunaan sistem akan meningkatkan kinerjanya. Orang menggunakan teknologi informasi karena mempunyai keyakinan bahwa prestasi dan kinerja akan meningkat. Konsep ini menggambarkan ukuran di mana penggunaan suatu teknologi dipercaya akan mendatangkan manfaat bagi pemakainya.

Kemudahan penggunaan yang dirasakan (perceived ease of use) menggambarkan tingkat kepercayaan seseorang bahwa penggunaan sistem informasi merupakan hal yang mudah dan tidak memerlukan usaha keras dari pemakainya. Kemudahan ini akan mengurangi tenaga, pikiran dan waktu yang digunakan untuk mempelajari dan menggunakan sistem informasi. Orang yang bekerja dengan sistem informasi, bekerja lebih mudah dibandingkan orang yang bekerja secara manual tanpa sistem informasi.

Sikap terhadap penggunaan (attitude towards use) merupakan kecenderungan tanggapan awal atas kondisi yang menyenangkan maupun tidak menyenangkan pada suatu objek tertentu. Secara teoritis, sikap merupakan refleksi perasaan seseorang atas objek dalam kondisi baik atau buruk, menguntungkan atau merugikan. Sikap muncul karena seseorang memiliki nilai yang ditentukan oleh kepercayaan atas objek tersebut. Pada kondisi lain, perilaku tertentu juga dapat mempengaruhi kepercayaan baru seseorang sehingga membawa perubahan pada sikap.

Perilaku (behavior) dilakukan karena individu mempunyai niat atau keinginan untuk melakukan atau niat berperilaku akan menentukan perilakunya. Niat berperilaku (behavioral intention) adalah suatu keinginan seseorang untuk melakukan suatu perilaku tertentu atau kecenderungan seseorang untuk tetap menggunakan teknologi tertentu. Tingkat penggunaan teknologi seseorang dapat diprediksi dari sikap perhatiannya terhadap teknologi tersebut, misal motivasinya untuk tetap menggunakan maupun memotivasi penggunaan lain atau menambah perangkat pendukung.

Perilaku adalah penggunaan sesungguhnya (actual usage) teknologi itu sendiri atau kondisi nyata penggunaan sistem informasi. Perilaku atau penggunaan sesungguhnya sulit diobservasi dan diukur melalui daftar pertanyaan. Hasil penelitian TAM, menunjukkan bahwa penggunaan sistem informasi dapat diprediksi dengan baik dengan menggunakan variabel niat berperilaku (behavioral intention) [3].

Beberapa penelitian yang telah dilakukan berkaitan dengan pengukuran penerimaan pengguna menggunakan TAM terhadap sistem e-learning di antaranya dilakukan oleh Akour et al. [8], Tselios and Daskalis [9], Al-Adwan et al. [10], Aziz et al. [11], Shahet al. [12], Buche et al. [13], dan Udzlmd et al. [14].

\section{METODOLOGI PENELITIAN}

Populasi dalam penelitian ini adalah seluruh user (pengguna) situs kuliah Universitas Atma Jaya Yogyakarta yang terbagi dalam 6 fakultas. Berdasarkan data populasi mahasiswa aktif yang diperoleh dari Kantor Sistem Informasi (KSI) Universitas Atma Jaya Yogyakarta, terdapat 11.401 mahasiswa yang aktif dalam kegiatan perkuliahan semester genap periode 2015/2016. Pengambilan sampel populasi menggunakan teknik simple random sampling. Menurut Fauzi [15] simple random sampling yaitu teknik untuk mendapatkan sampel yang langsung dilakukan pada unit sampling. Penentuan jumlah sampel berdasarkan populasi dilakukan dengan menggunakan rumus Slovin [16] dengan batas kesalahan sebesar $10 \%$ dengan tingkat kepercayaan 90\%. Berdasarkan rumus Slovin didapatkan 
jumlah sampel dalam penelitian ini adalah sebanyak 99 responden dengan tingkat kepercayaan penelitian ini sebesar $90 \%$.

Pengumpulan data dilakukan dengan metode kuesioner tertutup yang akan diisi oleh mahasiswa pengguna sistem $e$ learning. Penetapan skala pengukuran jawaban pada kuesioner menggunakan skala Likert yang merupakan skala yang biasa digunakan untuk mengukur sikap, pendapat, dan persepsi seseorang [17]. Jawaban setiap item kuesioner disusun dari gradasi sangat positif sampai negatif (sangat setuju, setuju, biasa, tidak setuju, dan sangat tidak setuju).

Variabel yang digunakan di dalam penelitian terdiri dari variabel eksogen serta variabel endogen. Variabel Perceived Ease of Use merupakan variabel eksogen penelitian yang terdiri atas tiga indikator, yaitu: fleksibilitas, mudah dipelajari serta dipahami, dan mudah untuk digunakan. Variabel yang termasuk ke dalam variabel endogen dalam penelitian adalah Perceived Usefullness yang terdiri dari indikator menambah efektivitas dari pekerjaan yang dilakukan, meningkatkan kinerja, serta meningkatkan efisiensi. Variabel endogen selanjutnya Behavioral Intention yang terdiri dari konstruk penambahan dari e-learning yang lain, motivasi untuk terus menggunakan, serta memotivasi pengguna lain. Attitude Towards Using merupakan variabel endogen yang terdiri dari indikator keuntungan yang diterima, perasaan menolak, serta perasaan ketika menggunakan sistem informasi. Actual System Usage terdiri dari indikator penggunaan nyata, dan frekuensi penggunaan. Variabel indikator konstruksi dapat dilihat pada Tabel 1.

TABEL I.

VARIABEL INDIKATOR KONSTRUKSI

\begin{tabular}{|c|c|}
\hline Konstruk & Variabel Indikator \\
\hline \multirow{6}{*}{$\begin{array}{l}\text { Perceived } \\
\text { Ease of Use } \\
\text { (PEU) }\end{array}$} & $\mathrm{X} 1$ = kemudahan dipelajari \\
\hline & $\mathrm{X} 2$ = mudah dipahami/dimengerti \\
\hline & X3 = mudah sehingga mahir \\
\hline & $\mathrm{X} 4=$ mudah digunakan \\
\hline & $\mathrm{X} 5$ = mudah dikendalikan \\
\hline & $\mathrm{X} 6=$ mudah diingat \\
\hline \multirow{6}{*}{$\begin{array}{l}\text { Perceived } \\
\text { Usefulness } \\
\text { (PU) }\end{array}$} & Y1 = lebih cepat \\
\hline & $\mathrm{Y} 2=$ meningkatkan kinerja \\
\hline & $\mathrm{Y} 3=$ meningkatkan produktivitas \\
\hline & Y4 = meningkatkan efektivitas \\
\hline & Y5 = lebih mudah \\
\hline & Y6 = bermanfaat \\
\hline \multirow{4}{*}{$\begin{array}{l}\text { Attitude } \\
\text { Toward Using } \\
\text { (ATU) }\end{array}$} & $\mathrm{Y} 7=$ rasa senang \\
\hline & $\mathrm{Y} 8=$ menikmati \\
\hline & Y9 $=$ rasa bosan \\
\hline & Y10= tidak suka \\
\hline \multirow{2}{*}{$\begin{array}{l}\text { Behavioral } \\
\text { Intention (BI) }\end{array}$} & Y10 = menggunakan kapan saja \\
\hline & Y11 = menggunakan kondisi apapun \\
\hline
\end{tabular}

\begin{tabular}{|l|l|}
\hline \multirow{2}{*}{} & Y12 = menggunakan terus \\
\cline { 2 - 2 } & $\mathrm{Y} 13=$ niat menggunakan terus \\
\cline { 2 - 2 } $\begin{array}{l}\text { Actual Usage } \\
\text { (AU) }\end{array}$ & $\mathrm{Y} 14=$ berharap menggunakan \\
\cline { 2 - 2 } & $\mathrm{Y} 15=$ frekuensi penggunaan \\
\hline
\end{tabular}

Penelitian ini menggunakan metode penelitian deskriptif. Penelitian deskriptif dapat dilakukan secara kuantitatif sehingga selanjutnya akan dilakukan analisis statistik. Dalam penelitian ini menggunakan alat atau tools SPSS (Statistical Product and Service Solution) dan AMOS (Analysis of Moment Structures).

Untuk menguji kevalidan kuesioner dilakukan uji validitas. Validitas adalah suatu ukuran yang menunjukkan tingkat validitas atau kesahihan suatu instrumen [18]. Menurut Ghozali [19] suatu kuesioner dikatakan valid jika pertanyaan pada kuesioner mampu untuk mengungkapkan sesuatu yang akan diukur oleh kuesioner tersebut. Uji signifikansi dilakukan dengan cara membandingkan nilai $r$ hitung dengan $r$ tabel untuk degree of freedom $(\mathrm{df})=\mathrm{n}-2$, dalam hal ini $\mathrm{n}$ adalah jumlah sampel. Untuk menguji validitas masing-masing indikator, dapat dilihat dalam tampilan output Cronbach Alpha pada kolom Correlated Item-Total Correlation. Jika $\mathrm{r}$ hitung lebih besar dari $\mathrm{r}$ tabel dan nilai positif maka butir atau pertanyaan atau indikator tersebut dinyatakan valid. Seluruh proses ini menggunakan software SPSS for Windows.

Selanjutnya dilakukan uji reliabilitas instrumen pada penelitian. Menurut Sugiyono [17], "instrumen yang valid umumnya pasti reliabel, tetapi pengujian reliabilitas instrumen perlu dilakukan". Selain itu, Sugiyono juga menyatakan bahwa reliabilitas berkenaan dengan derajat konsistensi dan stabilitas data atau temuan, sehingga alat pengukur/instrumen seharusnya memiliki kemampuan untuk memberikan hasil pengukuran relatif konsisten dari waktu ke waktu.

Uji normalitas digunakan untuk mengetahui apakah masing-masing variabel terdistribusi normal atau tidak [20]. Uji normalitas diperlukan untuk melakukan pengujian variabel lainnya dengan mengasumsikan bahwa nilai residual mengikuti distribusi normal. Jika asumsi ini dilanggar maka uji statistik menjadi tidak valid dan statistik parametrik tidak dapat digunakan.

Uji statistik yang digunakan untuk uji normalitas data dalam penelitian iniadalah uji normalitas dengan metode Skewness Kurtosis. Hasil analisis ini kemudian dibandingkan dengan nilai kritisnya. Pengujian normalitas secara univariate ini adalah dengan mengamati nilai skewness data yang digunakan, apabila nilai CR pada skewness data berada di antara rentang antara $+/-2,58$ pada tingkat signifikansi 0,05 , maka data penelitian yang digunakan dapat dikatakan normal. Jenis distribusi data terbagi dalam tiga bagian, yaitu: 1) Normal bila skewness $<2$ dan kurtosis $<7$.

2) Moderately non-normal, besarnya data yang tidak normal moderat (sedang). Nilai skewness antara 2 sampai 3 dan kurtosis antara 7 sampai 21. 
3) Extremely non-normal, yaitu distribusi data sangat tidak normal. Nilai skewness di atas 3 dan nilai kurtosis di atas 21

Tahap selanjutnya adalah mencari outliers. Outliers merupakan data yang memiliki karakteristik unik yang terlihat jauh dari observasi-observasi lainnya dan muncul dalam bentuk nilai ekstrim baik untuk konstruk tunggal maupun konstruk kombinasi [21]. Deteksi terhadap multivariate outliers dilakukan dengan berdasarkan nilai Mahalanobis Distance, berdasarkan dari nilai P1 atau P2. Jika salah satu nilai P1 dan P2 terdapat nilai kurang dari 0.05 maka observation number tersebut mengandung outlier.

Pengujian hipotesis pada penelitian ini dilakukan dengan menggunakan pendekatan Structural Equation Modelling (SEM). SEM merupakan persamaan yang digunakan untuk menggabungkan model pengukuran serta model struktural secara simultan. Untuk melakukan pengujian SEM maka terlebih dahulu dilakukan Test of Model Fit yang bertujuan untuk menguji kesesuaian model dengan data yang digunakan di dalam penelitian, yang terdiri atas:

- Pengujian Chi-Square, dilakukan dengan tujuan untuk membandingkan antara hasil pengujian yang didapat dari observasi dengan hasil yang diharapkan secara teoritis [22]. Di dalam pengujian Chi-square model dianggap sesuai apabila memiliki nilai yang rendah. Semakin kecil nilai Chi-square, maka model tersebut pun semakin baik.

- Goodness of Fit Index, mengukur tingkat keakurasian dari suatu model apabila digunakan untuk mengobservasi matrik kovarian, dengan cara mengukur rasio dari varian general yang dijelaskan terhadap jumlah keseluruhan dari varian general. Suatu model dianggap memiliki nilai yang baik jika berada di antara 0 dan 1 .

- CMIN/DF. The minimum sample discrepancy function (CMIN) dibagi dengan degrees of freedom akan menghasilkan indeks CMIN/DF [23]. Indeks ini merupakan salah satu indikator untuk mengukur tingkat fit-nya sebuah model dan jumlah-jumlah koefisien estimasi yang diharapkan untuk mencapai tingkat kesesuaian. Nilai yang direkomendasikan untuk menerima adalah CMIN/DF $<3,0$.

- Root Mean Square Error of Approximation (RMSEA), yaitu ukuran yang mencoba memperbaiki kecenderungan statistik Chi-squares menolak model dengan jumlah sampel yang besar [23]. Apabila suatu model memiliki nilai kurang dari 0,05 maka model tersebut sesuai. Analisis metode SEM dilakukan dengan menggunakan software AMOS 21. AMOS 21 memungkinkan pengolahan data menggunakan data mentah hasil dari skoring kuisioner yang kemudian secara otomatis diubah menjadi matrik kovarian yang nantinya akan digunakan untuk menguji hipotesis.

Model Penelitian yang akan diuji digambarkan pada Gambar 2:

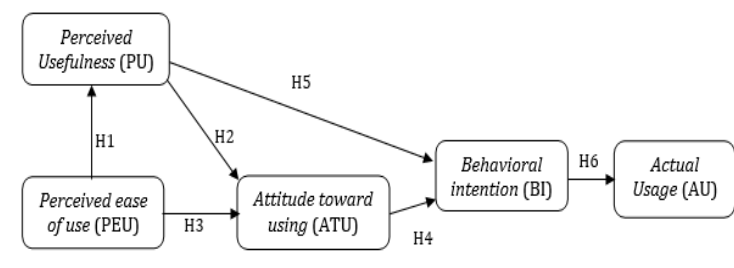

Gambar 2. Model Penelitian

Hipotesis yang akan diuji dalam penelitian ini adalah sebagai berikut:

H1: Persepsi Kemudahan Penggunaan (Perceived Ease of Use) berpengaruh positif terhadap Persepsi Kegunaan (Perceived Usefullness) pada penggunaan e-learning di UAJY.

H2: Persepsi Kegunaan (Perceived Usefullness) berpengaruh positif terhadap Sikap terhadap Perilaku (Attitude Towards Using) penggunaan e-learning di UAJY.

H3: Persepsi Kemudahan Penggunaan (Perceived Ease of Use) berpengaruh terhadap Sikap terhadap Perilaku (Attitude Towards Using) pada penggunaan e-learning di UAJY.

H4: Sikap terhadap Perilaku (Attitude Towards Using) berpengaruh positif terhadap NiatPerilaku (Behavioral Intention) pada penggunaan e-learning di UAJY.

H5: Persepsi Kegunaan (Perceived Usefullness) berpengaruh positif terhadap Niat Perilaku (Behavioral Intention) penggunaan e-learning di UAJY.

H6: Niat Perilaku (Behavioral Intention) berpengaruh terhadap Penggunaan Nyata Sistem (Actual System Usage) e-learning di UAJY.

\section{HASIL DAN PEMBAHASAN}

Kuesioner yang terkumpul sejumlah 202 buah. Dari 202 terdapat $2(0,9 \%)$ data yang tidak lengkap, jadi total data yang diperoleh dan layak dianalisis adalah $200(99,1 \%)$ data. Responden terdiri dari mahasiswa Fakultas Teknologi Industri (25,2\%), Fakultas Ekonomi (19,8\%), Fakultas Ilmu Sosial dan Ilmu Politik (13,8\%), Fakultas Teknik (20,2\%), Fakultas Teknobiologi $(10,8 \%)$, dan Fakultas Hukum $(9,9 \%)$.

\section{A. Analisis Data}

Uji validitas data dilakukan untuk melihat ada atau tidaknya korelasi antara variabel atau konstruk satu dengan konstruk. Uji validitas juga menguji kebenaran data yang akan disebarkan kepada responden. Pengujian ini dilakukan menggunakan SPSS dengan memakai Sig Pearson Corellation dan beberapa pengukur untuk menguji setiap variabel indikator yang akan diuji. Suatu kuesioner dikatakan valid jika pertanyaan pada kuesioner mampu mengungkapkan sesuatu yang akan diukur oleh kuesioner tersebut.

Dasar pengambilan keputusan dalam uji validitas adalah: 
1. Jika nilai rhitung > rtabel, maka item pertanyaan atau pertanyaan dalam kuesioner berkorelasi signifikan terhadap skor total (valid).

2. Jika nilai rhitung < rtabel, maka item pertanyaan atau pertanyaan dalam kuesioner tidak berkorelasi signifikan terhadap skor total (tidak valid).

Pada penelitian ini akan dilakukan uji validitas masingmasing variabel indikator dan dibandingkan dengan skor $\mathrm{R}$ Tabel untuk signifikansi 0,05 (5\%) dengan jumlah responden $\mathrm{N}=200$ adalah 0,138. Hasil uji untuk semua konstruk dinyatakan valid, karena mendapatkan skor $\mathrm{r}$ lebih besar dari 0,138 , sehingga kuesioner dinyatakan valid.

Menurut Ghozali [18] reliabilitas adalah alat untuk mengukur suatu kuesioner yang merupakan indikator dari variabel atau konstruk. Suatu kuesioner dikatakan reliabel atau handal jika jawaban seseorang terhadap pernyataan adalah konsisten atau stabil dari waktu ke waktu. Suatu konstruk atau variabel dinyatakan reliabel jika memberikan nilai Cronbach Alpha > 0.70. Pada penelitian ini dilakukan uji reliabilitas Alpha Cronbach's dengan SPSS 23. Setiap indikator akan dihitung nilai Alpha Cronbach's tiap indicator, lalu dibandingkan dengan nilai alpha pada populasi 202 responden yaitu 0,138 . Hasil uji menunjukkan semua indikator dinyatakan reliabel dengan nilai Cronbach Alpha > 0,70 .

\section{B. Analisis Structural Equation Model (SEM)}

1) Uji Asumsi Kecukupan Sampel

Jumlah data dari penelitian sebanyak 5 kali dari jumlah indicator [23]. Mengacu pada hal tersebut maka jumlah indikator dalam penelitian minimal 24 x $5=120$ orang. Berdasarkan penelitian tersebut sampel yang dibutuhkan dalam penelitian ini minimal 120 orang, yaitu mahasiswa Fakultas Teknologi Industri, Fakultas Ekonomi, Fakultas Teknik, Fakultas ISIP, Fakultas Teknobiologi, dan Fakultas Hukum yang menggunakan fasilitas e-learning. Jumlah data yang terkumpul adalah 202 sampel data.

\section{2) Evaluasi Outlier Model}

Outliers merupakan observasi atau data yang memiliki karakteristik unik atau data yang terlihat menyimpang terlalu jauh dari data yang lainnnya dalam sebuah rangkaian data. Dalam penelitian ini outliers dievaluasi dengan nilai mahalanobis dengan nilai degree of freedom sejumlah variabel pada tingkat $\mathrm{p}<0.05$. Jika salah satu nilai $\mathrm{P} 1$ dan $\mathrm{P} 2$ terdapat nilai kurang dari 0,05 maka observation number tersebut data yang mengandung outlier. Berdasarkan hasil perhitungan terdapat beberapa observation number memiliki nilai P1 dan P2 di bawah 0,05, sehingga dapat dipastikan bahwa data tersebut mengandung outlier. Berdasarkan hasil di atas terdapat beberapa outlier yaitu observation number 78, 70, dan 42 di mana data tersebut memiliki nilai P1 dan P2 di bawah 0,05. Untuk menangani data outlier tersebut maka data tersebut dihapus karena akan mempengaruhi distribusi data selanjutnya.

\section{3) Uji Normalitas}

Sebelum melakukan pengujian terhadap indikator variabel yang diobservasi di dalam penelitian, hal pertama yang harus dilakukan adalah memastikan bahwa data yang digunakan merupakan data yang terdistribusi normal. Pengujian normalitas secara univariate ini adalah dengan mengamati nilai skewness dan kurtosis data yang digunakan, apabila nilai CR pada skewness data berada di antara rentang antara -2,58 sampai 2,58 dan nilai kurtosis $<7$, maka data penelitian yang digunakan dapat dikatakan normal. Evaluasi normalitas diidentifikasi baik secara univariate maupun multivariate. Secara univariate untuk nilai-nilai dalam C.R Skewness memiliki nilai di antara $\pm 2,58$ yang berarti secara univariate sebaran data dianggap normal, sehingga dapat digunkan untuk estimasi pada analisis selanjutnya. Data dalam penelitian ini terdistribusi secara moderat atau normalitas sedang secara multivariate dengan nilai C.R kurtosis,$- 332<7$. Hasil uji normalitas dapat dilihat pada Tabel 2.

TABEL II

HASIL UJI NORMALITAS DENGAN AMOS

\begin{tabular}{|c|c|c|c|c|c|c|c|c|}
\hline \multirow{2}{*}{$\begin{array}{l}\text { Varia } \\
\text { bel }\end{array}$} & \multicolumn{2}{|c|}{$\mathrm{m}$} & \multirow{2}{*}{$\mathrm{m}$} & \multirow{2}{*}{\multicolumn{2}{|c|}{ kew }} & \multirow[b]{2}{*}{.r. } & \multicolumn{2}{|c|}{$\mathrm{k}$} \\
\hline & in & $a x$ & & & & & $\begin{array}{l}\text { urto } \\
\text { sis }\end{array}$ & .r. \\
\hline U3 &, $000^{2}$ & $\begin{array}{l}, 00 \\
0\end{array}$ & 5 & $2^{41}$ & - & $2,360^{-}$ &, 543 & 1,555 \\
\hline U2 &, $000^{2}$ & $\begin{array}{l}, 00 \\
0\end{array}$ & 4 & $5^{37}$ & - & 2,170 & $\begin{array}{l}1,06 \\
5\end{array}$ & 3,051 \\
\hline U1 &, $000^{2}$ & $\begin{array}{l}, 00 \\
0\end{array}$ & 5 & $\begin{array}{l}, 02 \\
9\end{array}$ & - &, $165^{-}$ &, 335 &, $959^{-}$ \\
\hline I5 &, $000^{2}$ & $\begin{array}{l}, 00 \\
0\end{array}$ & 5 & $2^{16}$ & - &, $926^{-}$ &, 700 & 2,006 \\
\hline I 4 &, $000^{2}$ & $\begin{array}{l}, 00 \\
0\end{array}$ & 5 & $g^{4} 44$ & - & 2,574 & 194 & $556^{\prime}$ \\
\hline I3 &, $000^{2}$ & $\begin{array}{l}, 00 \\
0\end{array}$ & 5 & 031 & ' & 176 &, 322 &, $922^{-}$ \\
\hline I2 &, $000^{2}$ & $\begin{array}{l}, 00 \\
0\end{array}$ & 4 & 007 & ' & 043 & $\begin{array}{l}1,04 \\
9\end{array}$ & 3,007 \\
\hline I1 &, $000^{2}$ & $\begin{array}{l}, 00 \\
0\end{array}$ & 5 & $i^{28}$ & - & 1,609 & 036 & $103^{\prime}$ \\
\hline TU4 &, $000^{3}$ & $\begin{array}{l}, 00 \\
0\end{array}$ & 5 & $\begin{array}{l}, 34 \\
5\end{array}$ & - & $\begin{array}{r}- \\
1,977\end{array}$ & $\begin{array}{l}1,56 \\
3\end{array}$ & 4, 479 \\
\hline TU3 &, $000^{3}$ & $\begin{array}{l}, 00 \\
0\end{array}$ & 5 & 218 & ' &, $252^{1}$ &, 866 & 2,481 \\
\hline TU2 &, $000^{2}$ & $\begin{array}{l}, 00 \\
0\end{array}$ & 5 & $\begin{array}{l}, 04 \\
3\end{array}$ & - & $.246^{-}$ &, 138 &, $396^{-}$ \\
\hline TU1 &, $000^{2}$ & $\begin{array}{l}, 00 \\
0\end{array}$ & 5 & 098 & ' & 559 &, 424 & 1,215 \\
\hline EU6 &, $000^{2}$ & $\begin{array}{l}, 00 \\
0\end{array}$ & 5 & $\begin{array}{l}, 16 \\
4\end{array}$ & - &, $938^{-}$ &, $006^{-}$ &, $016^{-}$ \\
\hline EU5 &, $000^{2}$ & $\begin{array}{l}, 00 \\
0\end{array}$ & 5 & 90 & - & $2,345^{-}$ & 534 &, $529^{1}$ \\
\hline EU4 &, $000^{2}$ & $\begin{array}{l}, 00 \\
0\end{array}$ & 5 & $\begin{array}{l}25 \\
6\end{array}$ & - & $1,465^{-}$ & 154 & $442^{\prime}$ \\
\hline EU3 &, $000^{3}$ & $\begin{array}{l}, 00 \\
0\end{array}$ & 5 & 108 & ' & 619 & 544 &, $559^{1}$ \\
\hline
\end{tabular}




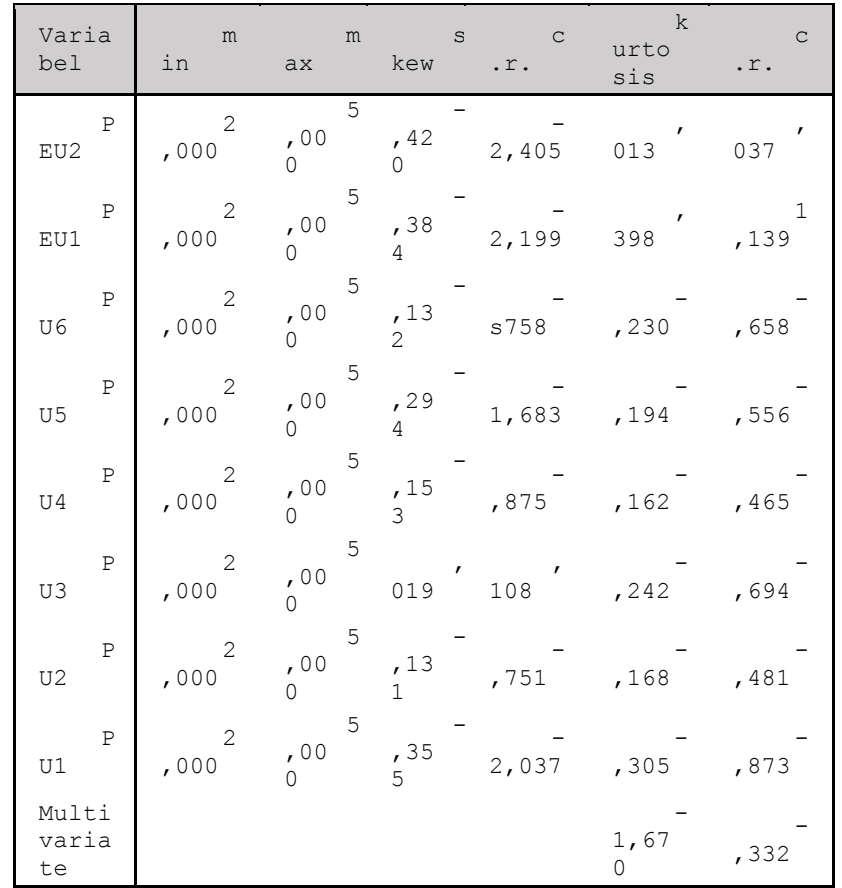

\section{4) Analisa Kesesuaian Model (Goodnes-of-Fit)}

Pengujian kesesuaian model digunakan untuk menguji sebarapa baik tingkat goodnes of fit dari model penelitian. Jika tingkat goodnes of fit baik, maka model penelitian akan digunakan dalam tahap Structural Equation Modelling. Tahap pertama adalah menguji goodnes of fit pada model penelitian. Tabel 3 menunjukkan hasil uji dengan menggunakan AMOS.

TABEL III

GOODNESS OF FIT INDEX

\begin{tabular}{|l|c|c|c|}
\hline $\begin{array}{l}\text { Goodness of } \\
\text { Index }\end{array}$ & Kriteria & $\begin{array}{l}\text { Cut of } \\
\text { Value }\end{array}$ & Keterangan \\
\hline Chi-square & $\begin{array}{l}<\text { Chi-Square } \\
\text { DF (124.342) }\end{array}$ & 347,2 & $\begin{array}{l}\text { Kurang } \\
\text { Baik }\end{array}$ \\
\hline RMSEA & $\leq 0.08$ & .046 & Baik \\
\hline GFI & $\geq 0.80$ & .875 & Fit \\
\hline AGFI & $\geq 0.80$ & .848 & Baik \\
\hline CMIN/DF & $\leq 2.00$ & 1.411 & Baik \\
\hline
\end{tabular}

Berdasarkan Tabel 3, hasil pengujian Goodnes of Fit index diketahui kriteria yang ada di antaranya yang berada pada kondisi baik atau fit. Namun ada beberapa hasil yang masih belum memenuhi kriteria seperti chi-square. Maka dari itu, dilakukan uji goodnes of fit dengan menggunakan variabel komposit (Gambar 3).

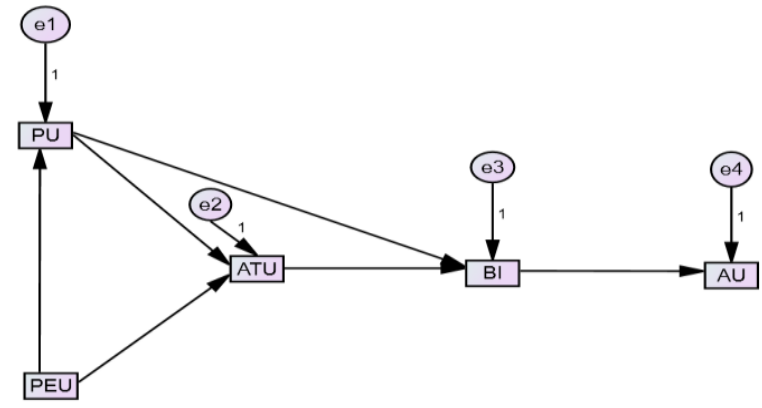

Gambar 3. Composite Path Diagram Technology Acceptance Model

Penggunaan variabel composite dikarenakan sudah melewati uji common method bias dan sudah termasuk latent factor di dalam masing-masing variabelnya. Atau dengan kata lain, model komposit menggabungkan variabel manifest ke dalam satu variabel laten sehingga menyebabkan model dengan variabel composite akan menjadi lebih sederhana dan akurat. Tabel 4 menunjukkan hasil perhitungan goodnes of fit dengan model SEM komposit.

TABEL IV

GOODNES OF FIT INDEX MODEL KOMPOSIT

\begin{tabular}{|l|c|c|c|}
\hline $\begin{array}{l}\text { Goodness } \\
\text { of Fit Index }\end{array}$ & Kriteria & $\begin{array}{l}\text { Cut of } \\
\text { Value }\end{array}$ & Keterangan \\
\hline $\begin{array}{l}\text { Chi- } \\
\text { square }\end{array}$ & $\begin{array}{l}<\text { Chi- } \\
\text { Square } \\
\text { DF } \\
(124.342)\end{array}$ & 20,173 & Baik \\
\hline Prob & $>0.05$ & .000 & Tidak Baik \\
\hline RMSEA & $\leq 0.08$ & .046 & Baik \\
\hline GFI & $\geq 0.80$ & .875 & Fit \\
\hline AGFI & $\geq 0.80$ & .848 & Baik \\
\hline CMIN/DF & $\leq 2.00$ & 1.411 & Baik \\
\hline
\end{tabular}

5) Analisis Koefision Jalur Path Analysis Structural Equation Modeling (SEM)

Pengujian model dalam Structural Equation Model dilakukan dengan dua pengujian, yaitu uji kesesuaian model dan uji signifikansi kausalitas melalui uji koefisien regresi. Hasil pengolahan data untuk analisis SEM terlihat pada tabel. Pada dasarnya hasil uji analisis SEM dalam penelitian merupakan hasil yang telah lulus uji modification indicies. Uji modification indicies dilakukan jika hasil Goodnes of Fit tidak memenuhi syarat dan perlu dilakukan perbaikan model sehingga menghasilkan kriteria Goodnes of Fit yang dapat diterima.

Pada hasil Tabel 4, nilai probability belum memenuhi persyaratan karena masih kurang dari 0,05, maka akan dilakukan modifikasi model dengan menelusuri kovarians pada output Modification Indicies. Setelah mendapatkan hasil dari modification indicies maka dilakukan modifikasi untuk mendapatkan probabilitas yang baik dan mendapatkan model yang sesuai dengan penelitian. Model hasil modification indicies ditunjukkan pada Gambar 4. 


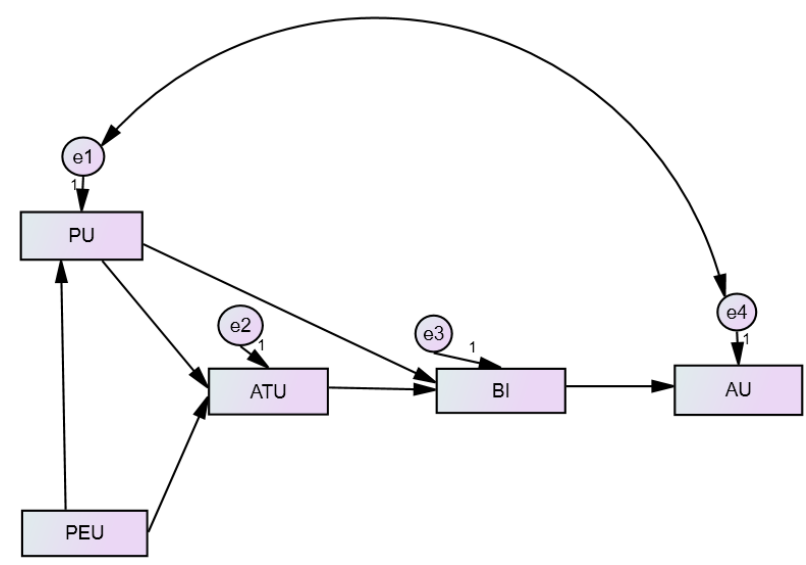

Gambar 4. Model Komposit setelah modifikasi

Pada model Gambar 4 diberikan alternatif perubahan yaitu e4 dengan e1. Pada model hasil modifikasi tersebut, jika e4 dikorelasikan dengan e1, maka nilai Chi-Square akan menurun sebesar 14,872. Adapun hasil modifikasi yang dilakukan berdasarkan rekomendasi program AMOS menghasilkan kriteria goodnes of fit seperti pada Tabel 5.

TABEL V

GOODNES OF FIT MODEL MODIFIKASI

\begin{tabular}{|l|r|c|c|}
\hline $\begin{array}{l}\text { Goodness } \\
\text { of Fit Inder }\end{array}$ & Kriteria & $\begin{array}{l}\text { Cut of } \\
\text { Value }\end{array}$ & Keterangan \\
\hline $\begin{array}{l}\text { Chi- } \\
\text { square }\end{array}$ & $\begin{array}{l}\text { <Chi- } \\
\text { Square } \\
\text { DF } \\
(124.342)\end{array}$ & 3,670 & Baik \\
\hline Prob & $>0.05$ & .299 & Baik \\
\hline RMSEA & $\leq 0.08$ & .034 & Baik \\
\hline GFI & $\geq 0.80$ & .993 & Fit \\
\hline AGFI & $\geq 0.80$ & .964 & Baik \\
\hline CMIN/DF & $\leq 2.00$ & 1.233 & Baik \\
\hline
\end{tabular}

Berdasarkan Tabel 5, dapat disimpulkan bahwa keseluruhan model dinyatakan sudah fit dan sesuai. Model yang diajukan penelitian ini didukung oleh fakta di lapangan. Hal ini merupakan indikasi bahwa dugaan matriks varianskovarians populasi sama dengan matriks varians-kovarians sampel atau data observasi. Maka selanjutnya akan dilihat hasil pengujian hipotesis melalui tabel Regression Weight Analisis. Hasil tabel Regression Weight adalah sebagai berikut (Tabel 6):

TABEL VI

REGRESSION WEIGHTS ANALISIS SEM

\begin{tabular}{|l|l|l|r|l|}
\hline $\begin{array}{l}\text { Hubungan } \\
\text { Variabel }\end{array}$ & Estimate & $\begin{array}{l}\text { Square } \\
\text { Error }\end{array}$ & $\begin{array}{r}\text { Critical } \\
\text { Ratio }\end{array}$ & $\begin{array}{l}\text { Pro- } \\
\text { babili } \\
\text { ty }\end{array}$ \\
\hline
\end{tabular}

\begin{tabular}{|c|c|c|c|c|}
\hline $\begin{array}{l}\text { Perceived } \\
\text { Ease of } \\
\text { Use } \rightarrow \\
\text { Perceived } \\
\text { Usefulnes }\end{array}$ & ,300 & 089 & 3,394 & $* * *$ \\
\hline $\begin{array}{l}\text { Perceived } \\
\text { Usefulnes } \\
\rightarrow \\
\text { Attitude } \\
\text { Toward } \\
\text { Using }\end{array}$ & ,180 & 031 & 5,862 & $* * *$ \\
\hline $\begin{array}{l}\text { Perceived } \\
\text { Ease of } \\
\text { Use } \rightarrow \\
\text { Attitude } \\
\text { Toward } \\
\text { Using }\end{array}$ & ,101 & 041 & 2,484 & 013 \\
\hline $\begin{array}{l}\text { Attitude } \\
\text { Toward } \\
\text { Using } \rightarrow \\
\text { Behaviora } \\
1 \text { Intention }\end{array}$ & ,436 & ,098 & 4,460 & $* * *$ \\
\hline $\begin{array}{l}\text { Perceived } \\
\text { Usefulnes } \\
\rightarrow \\
\text { Behaviora } \\
\text { 1 Intention }\end{array}$ & ,081 & ,046 & 1,757 & 079 \\
\hline $\begin{array}{l}\text { Behaviora } \\
1 \text { Intention } \\
\rightarrow \text { Actual } \\
\text { Usage }\end{array}$ & 094, & 035 & 2,695 & 007 \\
\hline
\end{tabular}

Hasil pengujian hipotesis dilakukan dengan menganalisis nilai Critical Ratio (CR) dan nilai Probability (P) hasil olah data, dibandingkan dengan batasan statistik yang disyaratkan, yaitu di atas 1,96 untuk nilai CR dan di bawah 0,05 untuk nilai $\mathrm{P}$ (probabilitas). Apabila hasil olah data menunjukkan nilai yang memenuhi syarat tersebut, maka hipotesis yang diajukan pada penelitan yang diajukan dapat diterima.

H1 - Persepsi Kemudahan (perceived ease of use) memiliki pengaruh terhadap Persepsi Manfaat (perceived usefulness)

Berdasarkan hasil pengolahan data diketahui nilai CR pada tabel di atas adalah sebesar 3,394 dan nilai $\mathrm{P}$ sebesar 0,000. Hasil dari kedua nilai ini memberikan informasi bahwa terdapat pengaruh Persepsi kemudahan terhadap persepsi manfaat, karena memenuhi syarat CR di atas 1,96 dan $\mathrm{P}$ di bawah 0,05. Dengan demikian dapat dikatakan bahwa hasil hipotesis 1 penelitian ini diterima. Hasil kontribusi yang diberikan persepsi kemudahan memberikan dampak peningkatan terhadap persepsi manfaat sebesar 0,300 setiap satu satuannya.

H2 - Persepsi manfaat (perceived usefulness) memiliki pengaruh terhadap sikap penggunaan (attitude toward using) 
Berdasarkan hasil pengolahan data diketahui nilai CR pada tabel di atas adalah sebesar 5,862 dan nilai $\mathrm{P}$ sebesar 0,000. Hasil dari kedua nilai ini memberikan informasi bahwa terdapat pengaruh Persepsi manfaat terhadap sikap penggunaan, karena memenuhi syarat $\mathrm{CR}$ di atas 1,96 dan $\mathrm{P}$ di bawah 0,05. Dengan demikian dapat dikatakan bahwa hasil hipotesis 2 penelitian ini diterima. Hasil kontribusi yang diberikan persepsi manfaat memberikan dampak peningkatan terhadap sikap penggunaan sebesar 0,180 setiap satu satuannya.

H3 - Persepsi kemudahan (percevied ease of use) memiliki pengaruh terhadap sikap penggunaan (attitude toward using)

Berdasarkan hasil pengolahan data diketahui nilai CR pada tabel di atas adalah sebesar 2,484 dan nilai $\mathrm{P}$ sebesar 0,013. Hasil dari kedua nilai ini memberikan informasi bahwa terdapat pengaruh Persepsi kemudahan terhadap sikap penggunaan, karena memenuhi syarat $\mathrm{CR}$ di atas 1,96 dan $\mathrm{P}$ di bawah 0,05. Dengan demikian dapat dikatakan bahwa hasil hipotesis 3 penelitian ini diterima. Hasil kontribusi yang diberikan persepsi kemudahan memberikan dampak peningkatan terhadap sikap penggunaan sebesar 0,101 setiap satu satuannya.

H4 - Sikap penggunaan (attitude toward using) memiliki pengaruh terhadap minat berperilaku (behavioral intention)

Berdasarkan hasil pengolahan data diketahui nilai CR pada tabel di atas adalah sebesar 4,460 dan nilai $\mathrm{P}$ sebesar 0,000 . Hasil dari kedua nilai ini memberikan informasi bahwa terdapat pengaruh sikap penggunaan terhadap minat berperilaku, karena memenuhi syarat $\mathrm{CR}$ di atas 1,96 dan $\mathrm{P}$ di bawah 0,05. Dengan demikian dapat dikatakan bahwa hasil hipotesis 4 penelitian ini diterima karena memenuhi syarat. Hasil kontribusi yang diberikan sikap penggunaan memberikan dampak peningkatan terhadap minat berperilaku sebesar 0,436 setiap satu satuannya.

H5 - Persepsi manfaat (perceived usefulness) memiliki pengaruh terhadap minat berperilaku (behavioral intention)

Berdasarkan hasil pengolahan data diketahui nilai CR pada tabel di atas adalah sebesar 1,757 dan nilai $\mathrm{P}$ sebesar 0,079. Hasil dari kedua nilai ini memberikan informasi bahwa tidak terdapat pengaruh persepsi manfaat terhadap minat berperilaku, karena tidak memenuhi syarat CR di atas 1,96 dan P di bawah 0,05. Dengan demikian dapat dikatakan bahwa hasil hipotesis 5 penelitian ini ditolak karena tidak memenuhi syarat. Hasil kontribusi yang diberikan persepsi manfaat memberikan dampak peningkatan terhadap minat berperilaku sebesar 0,081 setiap satu satuannya.

H6 - Minat berperilaku (behavioral intention) memiliki pengaruh terhadap penggunaan nyata (actual usage)

Berdasarkan hasil pengolahan data diketahui nilai CR pada tabel di atas adalah sebesar 2,695 dan nilai $\mathrm{P}$ sebesar 0,007. Hasil dari kedua nilai ini memberikan informasi bahwa terdapat pengaruh minat berperilaku terhadap penggunaan nyata, karena memenuhi syarat CR di atas 1,96 dan $\mathrm{P}$ di bawah 0,05. Dengan demikian dapat dikatakan bahwa hasil hipotesis 6 penelitian ini diterima dengan pengaruh positif. Hasil kontribusi yang diberikan minat berperilaku memberikan dampak peningkatan terhadap penggunaan nyata sebesar 0,094 setiap satu satuannya.

Tabel 6 menunjukkan rangkuman hasil pembuktian hipotesis.

TABEL VII

RANGKUMAN HASIL PEMBUKTIAN HIPOTESIS

\begin{tabular}{|l|l|}
\hline \multicolumn{3}{|c|}{ Hubungan Variabel } & Keterangan \\
\hline $\begin{array}{l}\mathrm{H} 1 \text { - Perceived Ease of Use } \\
\text { berpengaruh terhadap Perceived } \\
\text { Usefulnes }\end{array}$ & Diterima \\
\hline $\begin{array}{l}\text { H2 - Perceived Usefulnes berpengaruh } \\
\text { terhadap Attitude Toward Using }\end{array}$ & Diterima \\
\hline $\begin{array}{l}\mathrm{H} 3 \text { - Perceived Ease of Use } \\
\text { berpengaruh terhadap Attitude Toward } \\
\text { Using Diterima }\end{array}$ & \\
\hline $\begin{array}{l}\text { H4 Attitude Toward Using } \\
\text { berpengaruh terhadap Behavioral } \\
\text { Intention }\end{array}$ & Diterma \\
\hline $\begin{array}{l}\text { H5 - Perceived Usefulnes berpengaruh } \\
\text { terhadap Behavioral Intention }\end{array}$ & Ditolak \\
\hline $\begin{array}{l}\text { H6 - Behavioral Intention berpengaruh } \\
\text { terhadap Actual Usage }\end{array}$ & Diterima \\
\hline
\end{tabular}

Pada hipotesis pertama (H1) diketahui terdapat pengaruh persepsi kemudahan terhadap persepsi manfaat. Hal ini dikarenakan kemudahan dalam mengoperasikan sebuah sistem informasi juga mempengaruhi hasil yang diperoleh dari penggunaan tersebut. Kemudahan dalam mengoperasikan e-learning mempengaruhi pekerjaan mahasiswa sehingga proses belajar mengajar menggunakan e-learning menjadi lebih efektif, lebih cepat, dan meminimalkan tingkat kesalahan dalam penggunaan $e$ learning tersebut.

Pada hipotesis kedua (H2) terbukti bahwa terdapat pengaruh dari persepsi manfaat terhadap sikap terhadap penggunaan. Hasil penelitian menunjukkan bahwa ketika pengguna e-learning merasa bahwa pemanfaatan sistem informasi tersebut meningkatkan efektivitas serta efisiensi dari penyelesaian urusan akademik seperti mendapatkan materi kuliah, mengumpulkan tugas, berdiskusi mengenai materi kuliah maupun informasi perkuliahan maka mereka akan memiliki sikap menerima terhadap penggunaan $e$ learning perkuliahan tersebut. Hal ini dikarenakan manfaat yang didapatkan dalam penggunaan e-learning mempengaruhi sikap mahasiswa dalam penggunaan sistem informasi tersebut. Banyak mahasiswa UAJY yang merasa nyaman dan senang menggunakan situs kuliah karena memberikan manfaat sesuai dengan yang diinginkan, dan menyediakan fitur-fitur yang dibutuhkan mahasiswa. Namun sebaliknya juga jika persepsi mahasiswa terhadap manfaat $e$ learning tersebut cenderung negatif atau tidak memiliki manfaat, maka pengguna cenderung tidak suka atau bosan menggunakan sistem informasi tersebut karena sistem informasi tersebut tidak memberikan manfaat yang diinginkan oleh pengguna. 
Selanjutnya pada hipotesis ketiga (H3) terbukti bahwa persepsi kemudahan terdapat pengaruh terhadap sikap penggunaan. Hasil penelitian menunjukkan ketika pengguna e-learning UAJY merasa bahwa pemanfaatan sistem informasi tersebut akan meningkatkan efektivitas serta efisiensi dari penyelesaian urusan akademik mereka seperti misalnya mengumpulkan tugas, mencari materi kuliah, maupun informasi perkuliahan maka mereka akan memiliki sikap menerima terhadap penggunaan e-learning tersebut. Ketika mahasiswa merasa bahwa pemanfaatan e-learning membawa manfaat baginya maka mereka akan merasa nyaman serta tidak menolak penggunaan $e$-learning tersebut.

Pada hipotesis keempat (H4) hasilnya diterima. Hal ini dikarenakan sikap dalam penggunaan sistem informasi tersebut, baik positif maupun negatif, menentukan perilaku pengguna dalam waktu mendatang. Jika pengguna merasa nyaman dan senang, maka pengguna cenderung akan terus menggunakan sistem informasi tersebut untuk mengerjakan hal-hal lainnya. Selain itu, pengguna akan terus memotivasi pengguna lainnya untuk menggunakan sistem informasi tersebut. Demikian juga jika sikap pengguna terhadap suatu sistem informasi cenderung negatif, maka pengguna juga tentu tidak akan menggunakan sistem informasi tersebut dalam waktu mendatang dan mencari alternatif lain untuk menggantikan sistem informasi yang telah disediakan.

Pada hipotesis kelima (H5) hasilnya ditolak. Yaitu dimana persepsi manfaat mempengaruhi minat berperilaku. Hal ini dikarenakan kurangnya minat dari pengguna atau mahasiswa dalam menggunakan situs kuliah tersebut. Dalam hasil penelitian di atas sebagian besar mahasiswa merasakan manfaat yang nyata dalam penggunaan situs kuliah. Namun tidak mempengaruhi mahasiswa tersebut akan terus berniat menggunakan sistem informasi tersebut atau tidak. Minat pengguna terhadap sistem informasi lebih dipengaruhi oleh sikapnya, yaitu pengguna merasakan nyaman dan senang dalam penggunaannya, terlepas dari sistem informasi tersebut bermanfaat baginya atau tidak. Meskipun mahasiswa memandang bahwa pemanfaatan sistem informasi UAJY ini akan membantu mereka menyelesaikan tugas dan kewajiban perkuliahan secara lebih efektif namun hal tersebut hanya sebatas pemenuhan kebutuhan yang bersifat sebagai mahasiswa aktif UAJY. Persepsi manfaat tersebut tidak berpengaruh terhadap niat mahasiswa untuk meningkatkan performa e-learning maupun tendensi untuk tetap menggunakannya.

Hipotesis terakhir (H6), minat berperilaku memiliki pengaruh positif terhadap penggunaan nyata, diterima. Hal ini disebabkan perilaku pengguna sangat mempengaruhi penggunaan nyata yang dapat dilihat dari frekuensi penggunaan suatu sistem informasi. Dari hasil penelitian tersebut dapat disimpulkan bahwa apabila pengguna atau mahasiswa cenderung memiliki keinginan untuk terus menggunakan sistem informasi dan terus menggunakannya dalam berbagai pekerjaan, maka frekuensi penggunaan akan cenderung meningkat dalam waktu mendatang. Sebaliknya apabila pengguna yang memiliki minat yang kurang terhadap sistem informasi tersebut akan cenderung memiliki frekuensi penggunaan yang lebih sedikit atau jarang menggunakan sistem informasi tersebut.

\section{KESIMPULAN}

Dari keenam hipotesis yang diajukan, lima hipotesis dinyatakan diterima $(\mathrm{H} 1, \mathrm{H} 2, \mathrm{H} 3, \mathrm{H} 4, \mathrm{H} 6)$ dan satu hipotesis (H5) dinyatakan ditolak. Meskipun pengguna telah memahami dan merasakan manfaat dari e-learning namun hal itu tidak mempengaruhi minat untuk menggunakan sistem. Hal ini dapat terjadi karena meskipun seorang pengguna merasa bahwa penggunaan e-learning ini akan membantunya dalam menyelesaikan urusan akademik, namun karena pemanfaatan e-learning tersebut bersifat mandatori menyebabkan mereka tidak memiliki minat untuk tetap menggunakannya.

Hasil penelitian menunjukkan bahwa kemudahan penggunaan berpengaruh positif terhadap persepsi manfaat, dan sikap penggunaan. Hal tersebut menunjukkan bahwa apabila pengguna e-learning merasa bahwa sistem tersebut mudah digunakan maka akan memberikan manfaat bagi mahasiswa dan mempengaruhi penerimaan terhadap $e$ learning tersebut. Mahasiswa akan cenderung memiliki intensi untuk terus memanfaatkan sistem jika e-learning tersebut memenuhi kebutuhan mereka secara efisien. Sikap perilaku sendiri berpengaruh positif terhadap Niat berperilaku. Selanjutnya, hasil penelitian menunjukkan bahwa niat berperilaku berpengaruh positif terhadap penggunaan nyata. Pemanfaatan e-learning berbasis web merupakan suatu keharusan bagi mahasiswa UAJY sehingga hal tersebut mempengaruhi penggunaan nyata dari sistem tersebut yang ditunjukan dengan frekuensi pengaksesan web situs kuliah UAJY.

\section{DAFTAR PUSTAKA}

[1] Muhson, A., "Peningkatan Minat Belajar dan Pemahaman Mahasiswa melalui Penerapan Problem Based Learning", JurnalKependidikan, vol. 39, no. 2, pp. 171-182, November, 2009.

[2] Davis, F. D., "Perceived Usefullness, Perceived Ease of Use, and User Acceptance of Information Technology", MIS Quarterly, vol. 13, no.3, 1989.

[3] Venkatesh, V. and Davis, F.D. "A Theoretical Extension of the Technology Acceptance Model: Four Longitudinal Field Studies," Management Science, vol.46, no.2, pp. 186-204, 2000.

[4] Venkatesh, V., et al. "User acceptance of information technology: Toward a unified view", MIS Quarterly, vol. 27, no.3, pp 425-478, 2003.

[5] Davis, F. D. ,“A Technology Acceptance Model For Empirically Testing New End-User Information Systems: Theory And Results", Doctoral dissertation, Sloan School of Management, Massachusetts Institute of Technology, 1986. 
[6] Ajzen, I. and M. Fishbein,Understanding Attitudes and Predicting Social Behavior, New Jersey: Prentice-Hall, 1980.

[7] Davis, F.D., Bagozzi, R.P., and Warshaw, P.R. "User Acceptance of Computer Technology: A Comparison of Two Theoretical Models", Management Science, vol.35, no.8, 1989.

[8] Akour, A. I. and Dwairi, M. A.,"Testing Technology Acceptance Model in Developing Countries: The Case of Jordan", International Journal of Business and Social Science, vol. 2, no. 14, pp. 278 - 284,2011.

[9] Tselios, N., et al., "Assessing the Acceptance of a Blended Learning University Course", Educational Technology \& Society, vol. 14, no. 2, pp. 224-235, 2011.

[10] Al-Adwan, et al., "Exploring Students Acceptance of eLearning using Technology Acceptance Model in Jordanian Universities", International Journal of Education and Development using Information and Communication Technology, vol 9, no. 2, pp. 4-18, 2013.

[11] Aziz, A.L., et al.,"Pengaruh Kemudahan Penggunaan Terhadap Kemanfaatan Pada Sikap Pengguna ELearning”, Jurnal Administrasi Bisnis, vol. 6, no. 2, 2013.

[12] Shah, Ghias Ud Din., et al.,"Implementation of Technology Acceptance Model in e-Learning Environment in Rural and Urban Areas of Pakistan", World Applied Science Journal, vol. 27, no.11, pp. 1495 - 1507, 2013.

[13] Buche, M. W., et al., "Does Technology Acceptance Affect E-Learning in a Non-Technology Intensive Course?", Journal of Information Systems Education, vol.23, no. 1 , pp. $41-50,2012$.

[14] Udzlmd, D., et al., "Acceptance in the Deployment of Blended Learning as Learning Resource in Information Technology and Computer Science Program, Brawijaya University", in Asia-Pacific Conference on Computer Aided System Engineering (APCASE), 2014, pp. 131-135.

[15] Fauzi, Muchammad, Metode Penelitian Kuantitatif, Semarang : Walisongo, 2009.

[16] Sugiyono, Metode Penelitian Pendidikan (Pendekatan Kuantitatif, Kualitatif dan $R \& D)$, Bandung:Alfabeta, 2015.

[17] Sugiyono, Metode Penelitian Kuantitatif Kualitatif dan $R \& D$, Bandung: Alfabeta, 2008.

[18] Suharsimi, Prosedur Penelitian Suatu Pendekatan Praktek, Jakarta: PT. Rineka Cipta, 2010.

[19] Ghozali, Imam, Aplikasi Analisis Multivriate dengan Progam SPSS, Semarang: Badan Penerbit Universitas Diponegoro, 2011.
[20] Ghozali, Imam, Aplikasi Analisis Multivarite dengan SPSS, cetakan keempat, Semarang: Badan Penerbit Universitas Diponegoro, 2006.

[21] Hair, et al, Multivariate Data Analysis, 5 th ed., The Prentice Hall, 2006.

[22] Supangat, Andi, Statistika dalam Kajian Deskriftif, Inferensi dan Nonparametrik, edisi pertama, Jakarta: Kencana Prenada Media Group, 2007.

[23] Ghozali, I and Fuad, Structural Equation Modeling: Teori, Konsep, dan Aplikasi, Semarang: Badan Penerbit Universitas Diponegoro, 2005.

Lampiran. Pertanyaan Kuesioner

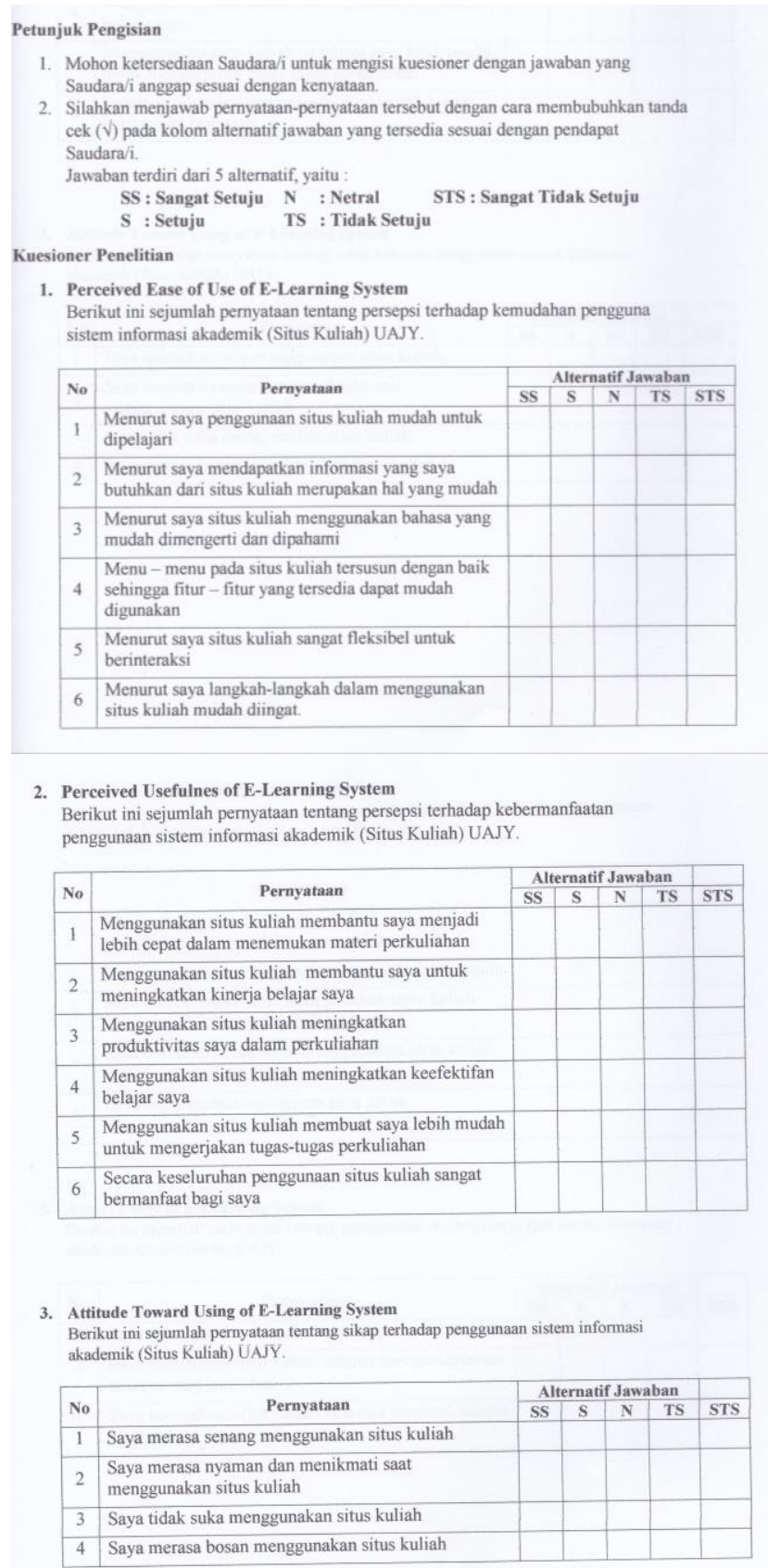


4. Behavioral Intention of E-Learning System

Berikut ini sejumlah pernyataan tentang minat berperilaku terhadap penggunaan sistem informasi akademik (Situs Kuliah) UAJY.

\begin{tabular}{|c|c|c|c|c|c|c|}
\hline \multirow{2}{*}{ No } & \multirow{2}{*}{ Pernyataan } & \multicolumn{4}{|c|}{ Alternatif Jawaban } & \multirow[b]{2}{*}{ STS } \\
\hline & & SS & $\mathbf{s}$ & $\mathbf{N}$ & TS & \\
\hline 1 & $\begin{array}{l}\text { Saya ingin menggunakan situs kuliah saat } \\
\text { perkuliahan maupun dalam mengerjakan tugas. }\end{array}$ & & & & & \\
\hline 2 & Saya ingin selalu menggunakan situs kuliah kapanpun & & & & & \\
\hline 3 & $\begin{array}{l}\text { Saya berniat ingin terus menggunakan situs kuliah } \\
\text { untuk mendukung proses belajar saya }\end{array}$ & & & & & \\
\hline 4 & $\begin{array}{l}\text { Saya berharap untuk terus menggunakan situs kuliah } \\
\text { dalam perkuliahan saya }\end{array}$ & & & & & \\
\hline 5 & $\begin{array}{l}\text { Saya ingin memotivasi teman saya untuk } \\
\text { menggunakan situs kuliah }\end{array}$ & & & & & \\
\hline
\end{tabular}

5. Actual Usage of E-Learning System

Berikut ini sejumlah pernyataan tentang penggunaan sesungguhnya dari sistem informasi akademik (Situs Kuliah) UAJY.

\begin{tabular}{|c|c|c|c|c|c|c|}
\hline \multirow[b]{2}{*}{ No } & \multirow{2}{*}{ Pernyataan } & \multicolumn{4}{|c|}{ Alternatif Jawaban } & \\
\hline & & SS & $\mathbf{s}$ & $\mathbf{N}$ & TS & STS \\
\hline 1 & Saya menggunakan situs kuliah minimal sehari sekali & & & & & \\
\hline 2 & $\begin{array}{l}\text { Saya mengakses situs kuliah selama hari perkuliahan } \\
\text { maupun saat hari libur }\end{array}$ & & & & & \\
\hline 3 & $\begin{array}{l}\text { Saya mengakses situs kuliah rata-rata minimal selama } \\
10 \text { menit }\end{array}$ & & & & & \\
\hline
\end{tabular}

